\title{
The effect on growth of Chlamydomonas reinhardtii of flue gas from a power plant based on waste combustion
}

\author{
Leiv M Mortensen ${ }^{*}$ and Hans R Gislerød
}

\begin{abstract}
Flue gases from a power plant based on waste combustion were tested as a carbon dioxide $\left(\mathrm{CO}_{2}\right)$ source for growing Chlamydomonas reinhardtii. To achieve recognition as an environmentally friendly hydrogen production method, waste gases should be used to grow this hydrogen-producing microalgae. The algae were grown in undiluted flue gas containing $11.4 \pm 0.2 \% \mathrm{CO}_{2}$ by volume, in diluted flue gas containing $6.7 \pm 0.1 \%$ or $2.5 \pm 0.0 \% \mathrm{CO}_{2}$, and in pure liquid $\mathrm{CO}_{2}$ at a concentration of $2.7 \pm 0.2 \%$. The $\mathrm{NO}_{x}$ concentration was $45 \pm 16 \mathrm{mg} \mathrm{m}^{-3}$, the $\mathrm{SO}_{2}$ concentration was $36 \pm 19 \mathrm{mg} \mathrm{m}^{-3}$, the $\mathrm{HCl}$ concentration $4.1 \pm 1.0 \mathrm{mg} \mathrm{m}^{-3}$ and the $\mathrm{O}_{2}$ concentration $7.9 \pm 0.2 \%$ in the undiluted flue gas. Undiluted flue gas reduced the dry weight production by around 20-25\% when grown at a photon flux density (PFD) of $300 \mu \mathrm{mol} \mathrm{m} \mathrm{s}^{-1}$ artificial light and at 24 or $33^{\circ} \mathrm{C}$, compared with the other treatments. A less negative effect was found at the highest flue gas concentration when the algae were grown at $75 \mu \mathrm{mol} \mathrm{m} \mathrm{s}^{-2} \mathrm{~s}^{-1}$ PFD. Growing the algae outdoors at a day length of $12.5 \mathrm{~h}$ and a temperature of around $24^{\circ} \mathrm{C}$, the dry weight production was higher (about $15 \%$ ) in the $2.6 \% \mathrm{CO}_{2}$ flue gas treatment compared with all other treatments. Reducing the light level by $30 \%$ through shading did not affect the dry weight production. Calculated on aerial basis the productivity reached approximately $70 \mathrm{~g} \mathrm{~m}^{-2}$ day $^{-1}$ in the $300 \mu \mathrm{mol} \mathrm{m} \mathrm{s}^{-2}$ PFD treatment (corresponding to $25 \mathrm{~mol} \mathrm{~m}^{-2}$ day ${ }^{-1}$ ) and approximately $17 \mathrm{~g} \mathrm{~m}^{-2}$ day ${ }^{-1}$ in the $75 \mu \mathrm{mol} \mathrm{m} \mathrm{s}^{-1}$ PFD treatment (corresponding to $6.5 \mathrm{~mol} \mathrm{~m}^{-2}$ day $^{-1}$ ). The outdoor production reached around $14 \mathrm{~g} \mathrm{~m}^{-2}$ day $^{-1}$. It was concluded that the negative effect of the undiluted flue gas was attributable to the high $\mathrm{CO}_{2}$ concentration and not to the other pollutants.
\end{abstract}

Keywords: Carbon dioxide concentration; Chlamydomonas reinhardtii; Flue gas; Photosynthetic active radiation

\section{Introduction}

The single-celled green alga Chlamydomonas reinhardtii is known to produce hydrogen when starved of sulphur under anaerobic conditions (Skjånes et al. 2007; Nguyen et al. 2011; Geier et al. 2012). At present, conventional hydrogen production is energy-intensive, and more environmentally friendly production based on biological processes is therefore of great interest (Jo et al. 2006). Today, the atmospheric $\mathrm{CO}_{2}$ concentration of about $400 \mu \mathrm{mol}$ $\mathrm{mol}^{-1}$ strongly limits the algal growth, and additional $\mathrm{CO}_{2}$ gas has to be supplied throughout the production phase (Geier et al. 2012). Waste $\mathrm{CO}_{2}$ from industrial flue gases should be used in order to make the production environmentally friendly. This will also contribute to reducing

\footnotetext{
* Correspondence: lei-mo@online.no

Department of Plant Science, The University of Life Sciences, Ås NO-1432, Norway
}

$\mathrm{CO}_{2}$ emissions that are important to the environment (IPCC 2013). Several studies have been carried out on the effect of flue gases on the growth of microalgae (Douskova et al. 2009; Kastanek et al. 2010; Borkenstein et al. 2011). Chlamydomonas reinhardtii seems to have been little studied, however (see review by van den Hende et al. 2012). Flue gases contain pollutants such as $\mathrm{NO}_{\mathrm{x}}$ and $\mathrm{SO}_{2}$ that can reach harmful levels depending on the species (van den Hende et al. 2012). However, few studies have devoted attention to whether the harmful effects depend on environmental factors such as irradiance level and temperature. In tomato plants, it is known that susceptibility to $\mathrm{NO}_{\mathrm{x}}$ is much higher in low-light as opposed to high-light conditions (Mortensen 1986). For microalgae, and particularly for C. reinhardtii, little is known about the modifying effects of climate factors. Therefore, in this work the effect of flue gas was studied on $C$. reinhardtii at

\section{穴 Springer}


different levels of artificial light and in outdoor conditions with and without shade, as well as at two temperature levels.

\section{Material and methods}

Chlamydomonas reinhardtii strain SAG 34.89 from SAG (Göttingen, Germany) obtained from the NIVA culture collection, Norway, was used in the experiments. The algae were stored on Petri dishes covered with TAP medium 1.5\% agar (Gorman and Levine 1965). The algae were grown in the high-salt Sueoka medium (Sueoka 1960). Sodium bicarbonate was used in the medium to buffer the culture at $10 \mathrm{mM}$. The microalgae were grown in $1.0 \mathrm{l}$ clear plastic bottles $(80 \mathrm{~mm}$ inner and $82 \mathrm{~mm}$ outer diameter) filled with $0.85 \mathrm{l}$ of growing medium (filled up to $17 \mathrm{~cm}$ ). Tubes with these dimensions have a volume of approximately 601 per $\mathrm{m}^{2}$ surface area when placed closely together, as the bottles were in the present experiments. The light was supplied by cool white fluorescence tubes (Osram L58W/840) 24 h day $^{-1}$ placed about $10 \mathrm{~cm}$ in front of the row of bottles. The photon flux density (PFD) of the artificial light was measured by a LI-COR Model Li-250 instrument with quantum sensor (400-700 nm). The light was supplied from one side and was measured at the surface of the bottles. However, inside the culture the light level strongly decreased from the light exposed side to the opposite side of the bottles, as well as with increasing cell concentration during growth. Typically, the light level decreased by about $70 \%$ through the $8.0 \mathrm{~cm}$ diameter bottle at start of the experiment and by more than $99.9 \%$ at the end of the experiment, due to the increase in the algae concentration.

Two experiments were carried out indoor with artificial light, while a third experiment was carried out outdoor in daylight. The daylight was measured by a Delta-T Devices PAR sensor (cosine corrected within $\pm 5 \%$ up to $70^{\circ}$ incidence). The temperature was controlled by placing the bottles with the microalgae culture in water baths controlled by aquarium heaters. A circulation pump ensured a homogenous temperature in the water baths. The temperature was measured by cupper-constantan thermocouples. The $\mathrm{CO}_{2}$ concentration was measured by a Vaisala $\mathrm{CO}_{2}$ transmitter (Type GMT221, range 0-5\%). The $\mathrm{CO}_{2}$ concentration as well as the temperatures and the daylight PAR were recorded as hourly means by a Campbell CR10X logger with an AM25T thermocouple multiplexer. In addition a Vaisala GMP instrument was used to measure the $\mathrm{CO}_{2}$ concentrations between 0 and $20 \%$, and the measurements were recorded as hourly means.

\section{The flue gas}

The flue gas was provided by 'Borregaard Waste to Energy' located in Sarpsborg, Norway (www.hafslund.no). This modern fuel-flexible energy recovery plant burns approximately 80,000 tonnes of waste-based fuel and produces approximately $230 \mathrm{GWh}$ per year. It has a high environmental standard. The $\mathrm{CO}_{2}, \mathrm{O}_{2}, \mathrm{NO}_{\mathrm{x}}, \mathrm{NO}, \mathrm{NO}_{2}$, $\mathrm{SO}_{2}, \mathrm{HCl}, \mathrm{CO}$ and $\mathrm{TOC}$ concentrations in the flue gas were measured at 10-minute intervals by an $\mathrm{ABB}$ Advance Cemas FTIR NT continuous monitoring system with extra modules for $\mathrm{O}_{2}$ and TOC measurements (Figure 1, Table 1). NO constituted the main part of the $\mathrm{NO}_{x}$, while $\mathrm{NO}_{2}$ contributed only $3.4 \pm 1.4 \%$ of the total $\mathrm{NO}+\mathrm{NO}_{2}$ (data not presented). The mean $\mathrm{O}_{2}$ concentration in the flue gas was $7.9 \pm 0.2 \%$. In addition, license measurements on a series of heavy metals and dioxins in the flue gas were performed 2-4 times per year since the start of the power plant in 2010 (Table 1).

Flue gas from the chimney was sucked by pumps through two $100 \mathrm{l}$ plastic tubs connected in series for condensation of water vapour. The microalgae were grown in undiluted flue gas $\left(11.4 \% \mathrm{CO}_{2}\right)$ or mixed with fresh air in a constant ratio using air pumps (Resun ACO-008A) to yield $6.7 \%$ and $2.5 \% \mathrm{CO}_{2}$, respectively (Figure 1, Table 1 ). One $\mathrm{CO}_{2}$ concentration $(2.66 \pm 0.16 \%)$ was established by mixing pure $\mathrm{CO}_{2}$ (food quality) from bottles with fresh air. The $\mathrm{CO}_{2}$ gas flow was determined by a capillary with a defined resistance, while the gas pressure was defined by the height of a water column. In this way, a very accurate $\mathrm{CO}_{2}$ flow could be added to a constant rate of fresh air supplied by air pumps (Resun ACO-001, ACO-004).

The different gas mixtures were bubbled through plastic tubes with $0.3 \mathrm{~cm}$ inner diameter to the bottom of the bottles at a rate of approximately $100 \mathrm{l} \mathrm{h}^{-1}$. All treatments in all experiments included three parallel bottles containing $0.85 \mathrm{l}$ of culture. Three independent experiments (including a total of 60 bottles) were carried out during the same time period, all of which started with the same algae concentration of $0.20 \mathrm{~g}$ dry weight per litre culture. This concentration was established by adding algae from a start culture. Two of the experiments were conducted indoor with artificial lighting while the third was conducted outdoor in daylight.

\section{Dissolved $\mathrm{CO}_{2}$ in the growth medium}

For algal growth, the concentration of dissolved $\mathrm{CO}_{2}$ in the nutrient medium is important and not the concentration of $\mathrm{CO}_{2}$ in the air bubbled into the culture, although a close relationship should be expected. In order to document this relationship a test with different concentrations of pure $\mathrm{CO}_{2}$ mixed with air were bubbled through the bottles filled with nutrient medium. The concentration of dissolved $\mathrm{CO}_{2}$ was measured using hand-held titration cells for titrimetric analysis (CHEMetrics Inc., USA, www. chemetric.com). The results showed that a progressive increase in the dissolved $\mathrm{CO}_{2}$ concentration from about 100 to about $500 \mathrm{mg} \mathrm{l}^{-1}$ with increasing $\mathrm{CO}_{2}$ concentration from about $1 \%$ up to about 20\% (Figure 2). Parallel to 

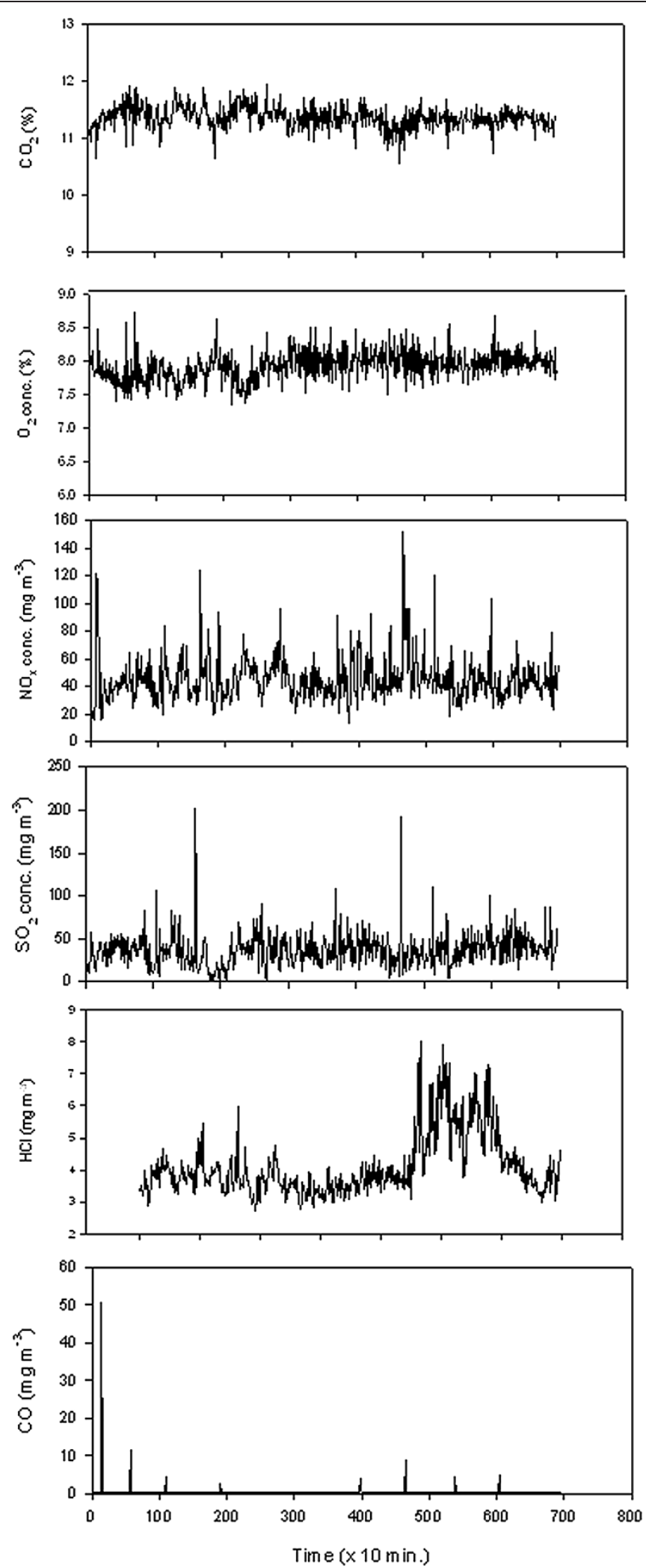

Figure 1 The concentration of different gases in undiluted flue gas. 
Table 1 Mean concentrations ( \pm SD) of different pollutants as measured in the different flue gas concentrations

\begin{tabular}{llll}
\hline & \multicolumn{3}{l}{$\mathrm{CO}_{\mathbf{2}}$ conc. (\%) } \\
\cline { 2 - 4 } & $\mathbf{1 1 . 3 7 \pm 0 . 1 9}$ & $\mathbf{6 . 7 1} \pm \mathbf{0 . 1 1}$ & $\mathbf{2 . 5 0} \pm \mathbf{0 . 0 4}$ \\
\hline $\mathrm{NO}_{x}\left(\mathrm{mg} \mathrm{m}^{-3}\right)$ & $45.0 \pm 15.8$ & $26.6 \pm 9.3$ & $9.9 \pm 3.5$ \\
$\mathrm{SO}_{2}\left(\mathrm{mg} \mathrm{m}^{-3}\right)$ & $36.1 \pm 19.0$ & $21.3 \pm 11.2$ & $7.9 \pm 4.2$ \\
$\mathrm{HCl}\left(\mathrm{mg} \mathrm{m}^{-3}\right)$ & $4.11 \pm 0.95$ & $2.43 \pm 0.56$ & $0.90 \pm 0.2$ \\
$\mathrm{CO}\left(\mathrm{mg} \mathrm{m}^{-3}\right)$ & $0.45 \pm 2.00$ & $0.27 \pm 1.18$ & $0.10 \pm 0.4$ \\
$\mathrm{TOC}\left(\mathrm{mg} \mathrm{m}^{-3}\right)$ & $0.714 \pm 0.436$ & $0.421 \pm 0.257$ & $0.157 \pm 0.096$ \\
${ }^{*} \mathrm{Hg}\left(\mu \mathrm{g} \mathrm{m}^{-3}\right)$ & $0.28 \pm 0.35$ & $0.17 \pm 0.21$ & $0.062 \pm 0.046$ \\
${ }^{*} \mathrm{HF}\left(\mathrm{mg} \mathrm{m}^{-3}\right)$ & $0.063 \pm 0.020$ & $0.037 \pm 0.012$ & $0.014 \pm 0.004$ \\
${ }^{*} \mathrm{Dioxins}\left(\mathrm{ng} \mathrm{m}^{-3}\right)$ & $0.00151 \pm 0.00134$ & $0.00089 \pm 0.00079$ & $0.00033 \pm 00029$ \\
${ }^{*} \mathrm{As}+\mathrm{Co}+\mathrm{Cr}+\mathrm{Cu}+\mathrm{Mn}$ & $0.0211 \pm 0.0545$ & $0.0124 \pm 0.0322$ & $0.0046 \pm 0.0120$ \\
$+\mathrm{Ni}+\mathrm{Pb}+\mathrm{Sb}+\mathrm{V}\left(\mathrm{mg} \mathrm{m}{ }^{-3}\right)$ & & & \\
\hline
\end{tabular}

The concentrations were measured continuously in the undiluted flue gas $(11.37 \%)$ and the concentrations in the diluted flue gases were reduced to the same extent as the $\mathrm{CO}_{2}$ concentration. *These concentrations were measured 2-4 times per year in the period 2010-2013 ( $n=10, \pm S D)$.

this increase the pH decreased from 7.6 to about 6.5. The measurements were done at $23^{\circ} \mathrm{C}$. Dissolved $\mathrm{CO}_{2}$ as measured at $7.0 \% \mathrm{CO}_{2}$ in the air was $311 \pm 12,297 \pm 12$ and $297 \pm 12 \mathrm{mg} \mathrm{l}^{-1}(\mathrm{n}=3, \pm \mathrm{SE})$ at 23,28 and $33^{\circ} \mathrm{C}$, respectively.

\section{The experiments}

\section{Experiment 1}

The microalgae were grown at the three flue gas concentrations and one concentration with pure $\mathrm{CO}_{2}$ from bottles (Figure 1, Table 1). Two photon flux densities (PFD) were continuously applied, 75 and $300 \mu \mathrm{mol} \mathrm{m}^{-2} \mathrm{~s}^{-1}$, corresponding to 6.5 and $25.9 \mathrm{~mol} \mathrm{~m}^{-2}$ day $^{-1}$ PAR, respectively. Two rows of twelve bottles with algae culture were placed closely adjacent to each other in a water bath. One row along one side of the water bath was exposed to $300 \mu \mathrm{mol} \mathrm{m} \mathrm{m}^{-2} \mathrm{~s}^{-1} \mathrm{PFD}$, and the other row along the opposite side was exposed to $75 \mu \mathrm{mol} \mathrm{m} \mathrm{m}^{-2}$ PFD. A black sheet across the water bath eliminated any light pollution between the two light treatments. The water bath was made of transparent plexiglass, and one and four fluorescent tubes placed 10-15 cm from the bottles (outside the water bath) produced the low and high PFD, respectively. The temperature was $33 \pm 2^{\circ} \mathrm{C}$. The dry weight ( $\mathrm{mg} \mathrm{l}^{-1}$ culture), $\mathrm{pH}$ and $\mathrm{O}_{2}$ concentration in the culture were measured after three and five days, and the production per $\mathrm{m}^{2}$ and day was calculated using the vertical projected area of the bottles.

\section{Experiment 2}

The same flue gas and pure $\mathrm{CO}_{2}$ gas treatments were applied in this experiment as in Experiment 1. In this experiment a PFD of $300 \mu \mathrm{mol} \mathrm{m}^{-2} \mathrm{~s}^{-1}$ given continuously was used. The temperature was $19 \pm 2^{\circ} \mathrm{C}$ during the first day, and was thereafter increased to $24 \pm 2^{\circ} \mathrm{C}$. The temperature was controlled as in Experiment 1. Twelve bottles were included in the experiment, and the dry weight concentration and $\mathrm{pH}$ were measured four and five days after the start.

\section{Experiment 3}

In this experiment the microalgae were grown outdoors during four days under the different $\mathrm{CO}_{2}$ treatments in full daylight and in $70 \%$ daylight by shading with white plastic (Figure 3 ). The bottles were closely placed adjacent to each other in water baths in rows with six bottles facing to the south. In the forefront row the culture received full daylight while the shade was given on the back row placed about $30 \mathrm{~cm}$ behind. Two water baths were needed for the 24 bottles including four $\mathrm{CO}_{2}$ and two light treatments. The temperature was as a mean $24^{\circ} \mathrm{C}$, varying from a peak of around $30^{\circ} \mathrm{C}$ at midday down to around $22^{\circ} \mathrm{C}$ during the night. The experiment was carried out in mid-September and the day length was $12.5 \mathrm{~h}(06.50-19.30 \mathrm{~h})$. The building of the power station was located a few meters north of the experiment. The PFD varied from 0 to a maximum of about $1600 \mu \mathrm{mol} \mathrm{m}^{-2} \mathrm{~s}^{-1}$ in full daylight and up to about 1100 $\mu \mathrm{mol} \mathrm{m} \mathrm{m}^{-2} \mathrm{~s}^{-1}$ in shaded conditions (Figure 2). The mean PAR was 17.1 and $12.0 \mathrm{~mol} \mathrm{~m}^{-2}$ day $^{-1}$ in full daylight and in shaded conditions, respectively. At the Meterological station $5 \mathrm{~km}$ from the experimental site (Østad, Sarpsborg, $59^{\circ} \mathrm{N}, 11^{\circ} \mathrm{E}$ ) the corresponding daylight was measured to $19.7 \mathrm{~mol} \mathrm{~m}^{-2} \mathrm{day}^{-1}$ when converted from global radiation to PAR (www.bioforsk.no, Agricultural Meteorological service). The higher measured value here was probably due to the light sensor with $180^{\circ}$ view (Kipp \& Zonen, CM11 pyranometer) and more diffuse light from the north since the building shaded for the light from this direction in the experiment. Mean effective PFD in the experiment was calculated by assuming that PFD above different threshold values $\left(100,200 \mu \mathrm{mol} \mathrm{m}^{-2} \mathrm{~s}^{-1}\right.$ etc.) has no effect on the growth (has reached the light saturation level) of the algae (Figure 4).

The dry weight was measured by vacuum filtering 10 or $20 \mathrm{ml}$ of culture through a $90 \mathrm{~mm}$ filter (Whatman GF/B, cat. No. 1821-090) and drying it in an oven for four hours at $100^{\circ} \mathrm{C}$. No pore size of this filter is given, however, all algal cells remained on the filter since no colouration of the filtered water was observed. The data were analysed using the SAS-GLM procedure (SAS institute Inc., Cary, USA) based on the bottles as replicates $(\mathrm{n}=3)$.

\section{Results}

\section{Experiment 1}

From an initial concentration of $0.2 \mathrm{~g} \mathrm{l}^{-1}$, the dry weight reached its maximum level after three days at the highest PFD, since no further increase was found on the fifth 

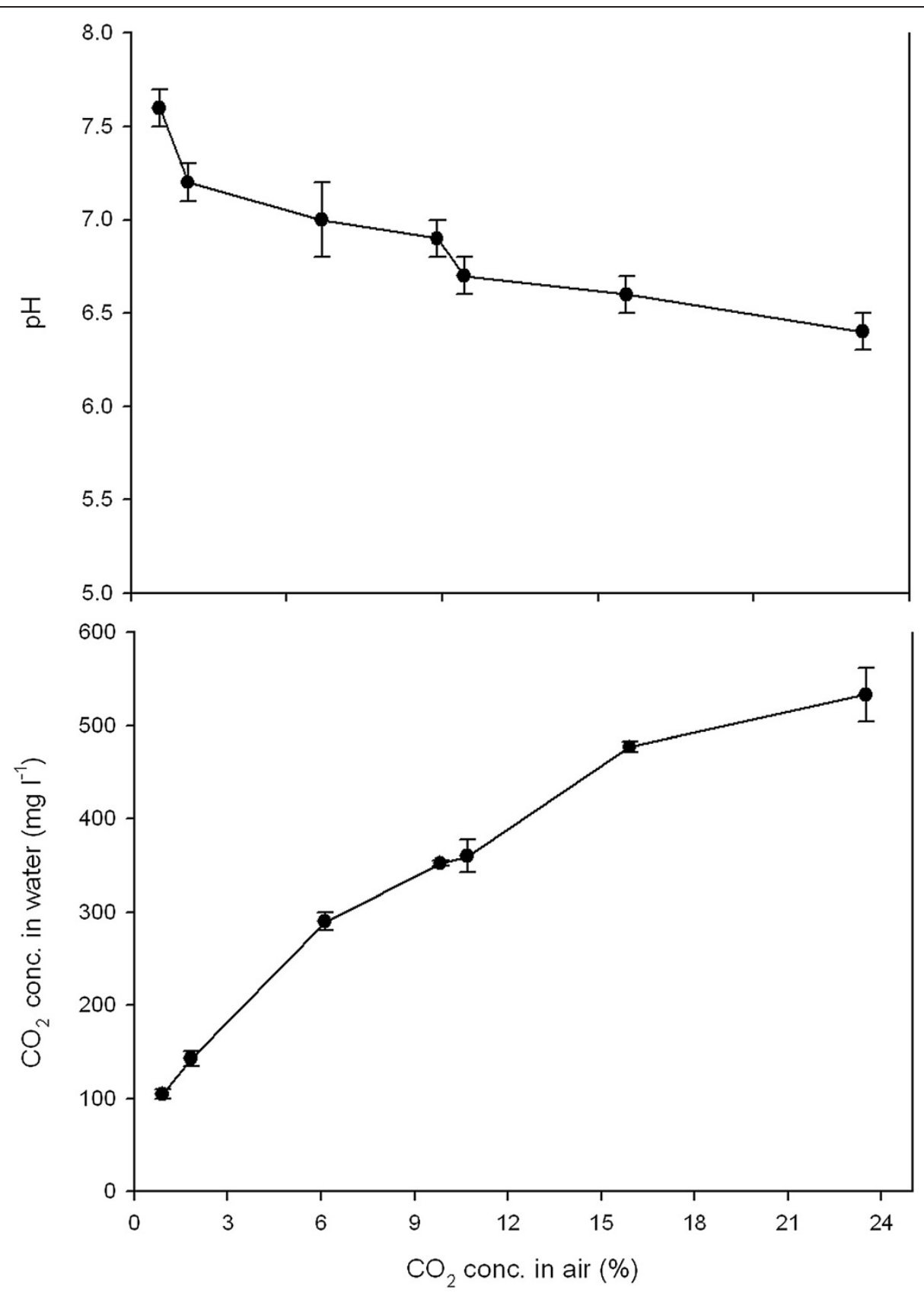

Figure 2 The concentration of $\mathrm{CO}_{2}$ dissolved in the culture and $\mathrm{pH}$ of the growth medium as influenced by the $\mathrm{CO}_{2}$ concentration in the air bubbled through the bottles (means, $\pm \mathrm{SE}$ ).

day (Table 2). At low PFD, the algae concentration continued to grow until the fifth day. The dry weight production during the first three days was significantly lower in the $11.4 \% \mathrm{CO}_{2}$ flue gas treatment (about 20\%) than in the $6.7 \%$ and $2.5 \% \mathrm{CO}_{2}$ flue gas treatments at $300 \mu \mathrm{mol} \mathrm{m} \mathrm{m}^{-2} \mathrm{~s}^{-1}$ PFD, while the decrease was less (5$10 \%)$ in the low PFD treatment. The dry weights at the two lower flue gas concentrations were slightly higher compared with the $2.6 \%$ control $\mathrm{CO}_{2}$ treatment using pure liquid gas. The dry weight production per day was about four times higher at 300 than at $75 \mu \mathrm{mol} \mathrm{m} \mathrm{s}^{-2}$ PFD, reaching about $70 \mathrm{~g} \mathrm{~m}^{-2}$ day $^{-1}$. The dry weight produced per mol photosynthetic active photons was the same at both PFD levels. Increasing the flue gas concentration slightly decreased the $\mathrm{O}_{2}$ content and decreased the $\mathrm{pH}$ in the algae culture. Increasing the light level slightly increased the $\mathrm{O}_{2}$ content and decreased the $\mathrm{pH}$. 


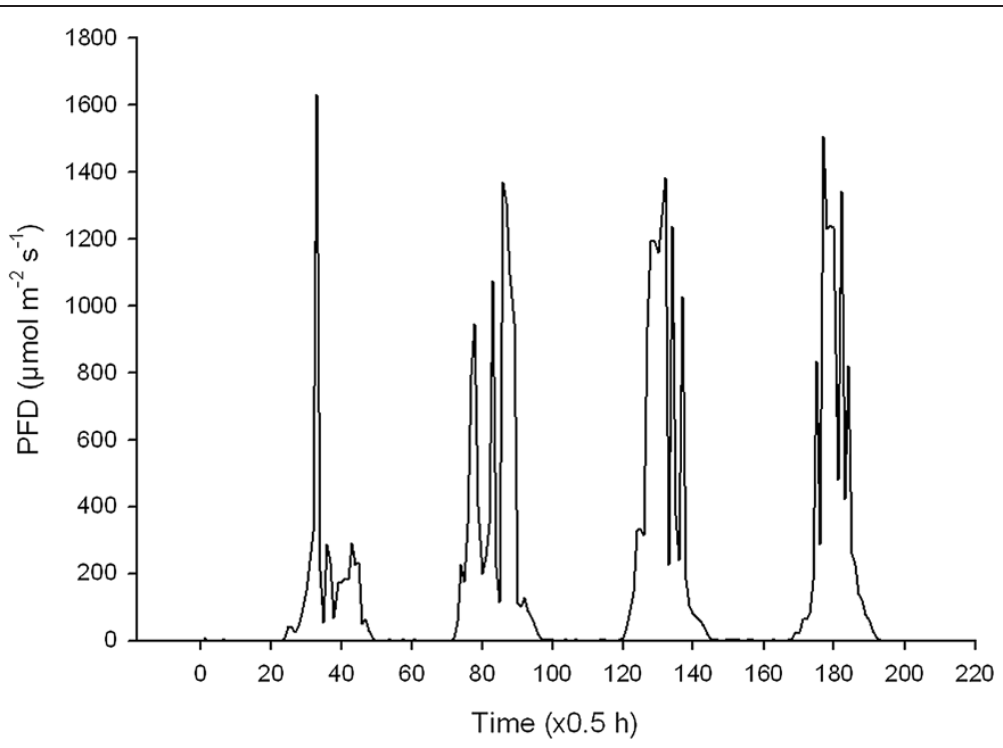

Figure 3 The photon flux density (PFD) of daylight during the experimental period.

\section{Experiment 2}

The dry weight concentration increased significantly from the fourth to the fifth day in this experiment when the algae were grown at $300 \mu \mathrm{mol} \mathrm{m} \mathrm{m}^{-2} \mathrm{~s}^{-1} \mathrm{PFD}$ and $24 \pm 2^{\circ} \mathrm{C}$ (Table 3). The dry weight production was significantly lower (about 25\%) at the highest flue gas concentration compared with the other treatments. The increase in algae concentration from 1.6 to $2.9 \mathrm{~g} \mathrm{l}^{-1}$ from the fourth to the fifth day resulted in an algal production of around $80 \mathrm{~g}$ $\mathrm{m}^{-2}$ day $^{-1}$ in the different treatments, except in the $11.4 \%$
$\mathrm{CO}_{2}$ flue gas treatment, where the production was around $60 \mathrm{~g} \mathrm{~m}^{-2}$ day $^{-1}$. At the end of the experiment, the $\mathrm{pH}$ decreased from 6.8 to 6.0 when the flue gas concentration was increased from the lowest to the highest level.

\section{Experiment 3}

Reducing daylight by $30 \%$ shade had no significant effect on the growth of the algae (Table 4). The dry weight production was $12-14 \mathrm{~g} \mathrm{~m}^{-2} \mathrm{day}^{-1}$ as a mean during four days. In this experiment, the dry weight production was

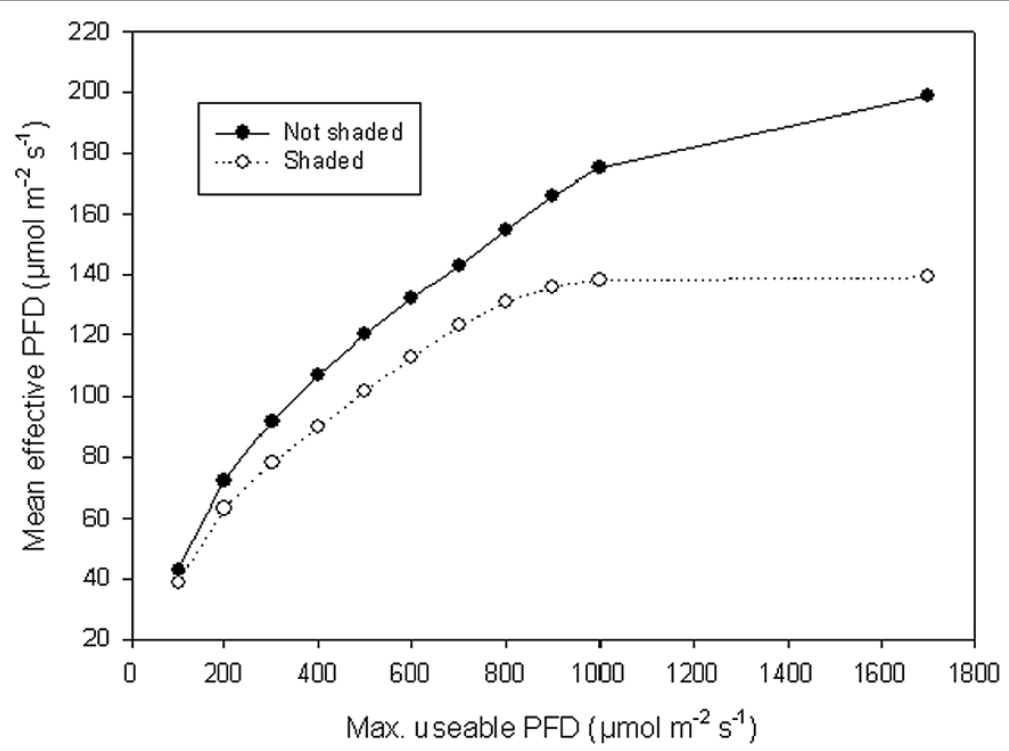

Figure 4 Mean effective PFD at different threshold values of daylight useable for the growth of the microalgae. PFD values above the threshold value were set to the threshold value, i.e. if PFD values above $300 \mu \mathrm{mol} \mathrm{m} \mathrm{s}^{-2}$ are recognised as having no effect, the effective PFD was set to $300 \mu \mathrm{mol} \mathrm{m} \mathrm{m}^{-2}$. 
Table 2 The effect of different $\mathrm{CO}_{2}$ concentrations supplied by flue gas ( $\mathrm{FI}$ ) and one concentration supplied by pure liquid $\mathrm{CO}_{2}$ gas (C) on $\mathrm{pH}, \mathrm{O}_{2}$ concentration in the culture and dry weight concentration ( $n=3, \pm \mathrm{SE}$ ) after 3 and 5 days of $C$. reinhardtii grown at 75 and $300 \mu \mathrm{mol} \mathrm{m} \mathrm{m}^{-2} \mathrm{~s}^{-1}$ PFD

\begin{tabular}{|c|c|c|c|c|c|c|c|c|c|}
\hline \multirow[b]{3}{*}{$\mathrm{CO}_{2}$ treatment } & \multirow[b]{3}{*}{ PFD } & \multicolumn{3}{|l|}{ Day 3} & \multicolumn{2}{|l|}{ Day 5} & \multirow{2}{*}{\multicolumn{3}{|c|}{$\begin{array}{l}\text { Mean dry weight production } \\
\text { Day } 0 \text { - } 3\end{array}$}} \\
\hline & & & & & & & & & \\
\hline & & $\mathrm{pH}$ & $\mathrm{O}_{2}\left(\mathrm{mg} \mathrm{l}^{-1}\right)$ & Dry w. $\left(\mathrm{mg} \mathrm{l}^{-1}\right)$ & $\mathrm{pH}$ & Dry w. $\left(\mathrm{mg} \mathrm{l}^{-1}\right)$ & $\mathrm{mg} \mathrm{l}^{-1}$ day $^{-1}$ & $\mathrm{~g} \mathrm{~m}^{-2}$ day $^{-1}$ & $\mathrm{~g} \mathrm{~mol}^{-1}$ \\
\hline $2.6 \% \subset$ & 75 & $7.1 \pm 0.0$ & $7.5 \pm 0.2$ & $798 \pm 27$ & $6.9 \pm 0.1$ & $1360 \pm 149$ & $266 \pm 9$ & $16.2 \pm 0.6$ & $2.50 \pm 0.09$ \\
\hline $2.6 \% C$ & 300 & $7.0 \pm 0.1$ & $8.3 \pm 0.1$ & $3297 \pm 46$ & $6.8 \pm 0.1$ & $3040 \pm 94$ & $1099 \pm 15$ & $67.0 \pm 0.9$ & $2.59 \pm 0.04$ \\
\hline $2.5 \% \mathrm{FI}$ & 75 & $7.3 \pm 0.1$ & $7.8 \pm 0.4$ & $877 \pm 84$ & $7.1 \pm 0.1$ & $1338 \pm 88$ & $292 \pm 28$ & $17.8 \pm 1.7$ & $2.74 \pm 0.26$ \\
\hline $2.5 \% \mathrm{FI}$ & 300 & $7.0 \pm 0.0$ & $8.5 \pm 0.1$ & $3527 \pm 48$ & $6.8 \pm 0.1$ & $3423 \pm 91$ & $1175 \pm 16$ & $71.7 \pm 0.9$ & $2.77 \pm 0.04$ \\
\hline $6.7 \% \mathrm{FI}$ & 75 & $7.0 \pm 0.1$ & $7.0 \pm 0.3$ & $845 \pm 36$ & $6.6 \pm 0.1$ & $1343 \pm 70$ & $282 \pm 12$ & $17.2 \pm 0.8$ & $2.64 \pm 0.12$ \\
\hline $6.7 \% \mathrm{FI}$ & 300 & $6.7 \pm 0.0$ & $7.5 \pm 0.2$ & $3663 \pm 124$ & $6.4 \pm 0.2$ & $3343 \pm 91$ & $1221 \pm 41$ & $74.5 \pm 2.5$ & $2.89 \pm 0.10$ \\
\hline $11.4 \% \mathrm{FI}$ & 75 & $6.8 \pm 0.1$ & $6.4 \pm 0.2$ & $777 \pm 14$ & $6.5 \pm 0.1$ & $1147 \pm 23$ & $259 \pm 5$ & $15.8 \pm 0.3$ & $2.43 \pm 0.04$ \\
\hline $11.4 \% \mathrm{Fl}$ & 300 & $6.7 \pm 0.1$ & $7.3 \pm 0.2$ & $2933 \pm 36$ & $6.5 \pm 0.1$ & $2843 \pm 45$ & $978 \pm 12$ & $59.6 \pm 0.7$ & $2.30 \pm 0.03$ \\
\hline \multicolumn{10}{|c|}{ F-value and significance level: } \\
\hline $\mathrm{CO}_{2}$ & & $64.5^{* * *}$ & $50.9^{* * *}$ & $17.6^{* * *}$ & $25.6^{* * *}$ & $3.54^{*}$ & $17.6^{* * *}$ & $17.6^{* * *}$ & $5.73^{* *}$ \\
\hline PFD & & $91.1^{* * *}$ & $77.4^{* * *}$ & $3512^{* * *}$ & $10.7^{* *}$ & $403^{* * *}$ & $3511^{* * *}$ & $3511^{* * *}$ & 0.51 \\
\hline $\mathrm{CO}_{2} \times \mathrm{PFD}$ & & $3.79^{*}$ & 0.59 & $10.9^{* * *}$ & 1.32 & 1.25 & $10.9^{* * *}$ & $10.9^{* * *}$ & 0.89 \\
\hline
\end{tabular}

The productivity during the first three days was calculated as the increase in culture concentration, in $\mathrm{g}$ dry weight production per $\mathrm{m}^{2}$ and day, as well as in $\mathrm{g}$ dry weight produced per mol of photosynthetic active radiation. F-values and significance levels are stated as follows: ${ }^{*} p<0.05 ;{ }^{* *} p<0.01 ;{ }^{* * *} p<0.001$.

$10-20 \%$ higher in the $2.5 \% \mathrm{CO}_{2}$ flue gas treatment than in the other treatments. The production per mol photons was increased $40-50 \%$ by $30 \%$ shading.

\section{Discussion}

The undiluted flue gas containing $11.4 \% \mathrm{CO}_{2}$ caused a decrease in the dry weight production compared with lower flue gas concentrations (2.5 and 6.7\%). This was particularly the case when the dry weight production was very high (up to $70-80 \mathrm{~g} \mathrm{~m}^{-2} \mathrm{day}^{-1}$ ), obtained at 300 $\mu \mathrm{mol} \mathrm{m} \mathrm{m}^{-2}$ PFD continuously applied $\left(25.9 \mathrm{~mol} \mathrm{~m}^{-2}\right.$ day $^{-1}$ PAR). In low-light conditions, (continuously 75 $\mu \mathrm{mol} \mathrm{m} \mathrm{m}^{-2} \mathrm{~s}^{-1}$ PFD or $6.5 \mathrm{~mol} \mathrm{~m}^{-2}$ day $^{-1}$ PAR) or in sunny daylight with a day length of $12.5 \mathrm{~h}\left(17.2 \mathrm{~mol} \mathrm{~m}^{-2}\right.$ day $^{-1}$ PAR) when the growth rate was much lower, less or no negative effect was found of the undiluted flue gas. The question was whether the negative effect was related to the high $\mathrm{CO}_{2}$ concentration itself or to the accompanying air pollutants. Separate measurements indicated that the dissolved $\mathrm{CO}_{2}$ concentration in the culture with undiluted flue gas might be about $400 \mathrm{mg} \mathrm{l}^{-1}$ as compared with about $150 \mathrm{mg} \mathrm{l}^{-1}$ in diluted flue gas with a concentration of $2.5 \% \mathrm{CO}_{2}$. This is far below the saturating level of $\mathrm{CO}_{2}$ in water that is about $1500 \mathrm{mg} \mathrm{l}^{-1}$ at $23^{\circ} \mathrm{C}$ and $1200 \mathrm{mg} \mathrm{l}^{-1}$ at $33^{\circ} \mathrm{C}$. The present pollutant levels of $\mathrm{NO}_{\mathrm{x}}$ and $\mathrm{SO}_{2}$ below about $50 \mathrm{mg} \mathrm{m}^{-3}$ in the flue gas seldom seem to cause growth reduction in microalgae (Matsumoto et al. 1997; Douskova et al. 2010; van den Hende et al. 2012; Farrelly et al. 2013; Jiang et al. 2013). Other flue gas compounds such as $\mathrm{CO}, \mathrm{HCl}, \mathrm{HF}$ and heavy metals such as $\mathrm{Hg}$ have received little attention so far (van den Hende et al. 2012). Probably the concentrations

Table 3 The effect of different $\mathrm{CO}_{2}$ concentrations supplied by flue gas (FI) and one concentration supplied by pure liquid $\mathrm{CO}_{2}$ gas (C) on $\mathrm{pH}$ and dry weight concentration $(n=3, \pm \mathrm{SE})$ after 4 and 5 days of $\mathrm{C}$. reinhardtii grown at $300 \mu \mathrm{mol} \mathrm{m} \mathrm{s}^{-1}$ PFD

\begin{tabular}{|c|c|c|c|c|c|c|c|}
\hline & \multicolumn{2}{|l|}{ Day 4} & \multicolumn{2}{|l|}{ Day 5} & \multicolumn{3}{|c|}{ Dry weight increase } \\
\hline & $\mathrm{pH}$ & Dry w. $\left(\mathrm{mg} \mathrm{l}^{-1}\right)$ & $\mathrm{pH}$ & Dry w. $\left(\mathrm{mg} \mathrm{l}^{-1}\right)$ & $\left(\mathrm{mg} \mathrm{l}^{-1} \mathrm{day}^{-1}\right)$ & $\mathrm{g} \mathrm{m}^{-2}$ day $^{-1}$ & $\mathrm{~g} \mathrm{~mol}^{-1}$ \\
\hline $2.6 \% \mathrm{C}$ & $7.1 \pm 0.1$ & $1457 \pm 56$ & $6.9 \pm 0.1$ & $2810 \pm 141$ & $1353 \pm 92$ & $82.6 \pm 5.6$ & $3.19 \pm 0.22$ \\
\hline $2.5 \% \mathrm{FI}$ & $7.0 \pm 0.0$ & $1622 \pm 21$ & $6.8 \pm 0.1$ & $2943 \pm 48$ & $1321 \pm 51$ & $80.6 \pm 3.1$ & $3.11 \pm 0.12$ \\
\hline $6.7 \mathrm{Fl}$ & $6.5 \pm 0.1$ & $1635 \pm 21$ & $6.3 \pm 0.1$ & $2917 \pm 100$ & $1282 \pm 79$ & $78.2 \pm 4.9$ & $3.02 \pm 0.19$ \\
\hline $11.4 \% \mathrm{FI}$ & $6.4 \pm 0.1$ & $1377 \pm 42$ & $6.0 \pm 0.3$ & $2380 \pm 81$ & $1003 \pm 54$ & $61.2 \pm 3.3$ & $2.36 \pm 0.13$ \\
\hline \multicolumn{8}{|c|}{ F-value and significance level: } \\
\hline $\mathrm{CO}_{2}$ & $49.8^{* * *}$ & $17.6^{* * *}$ & $20.4^{* * *}$ & $7.31^{*}$ & $5.24^{*}$ & $5.24^{*}$ & $5.24^{*}$ \\
\hline
\end{tabular}

The productivity from day four to five was calculated as the increase in culture concentration, in $\mathrm{g}$ dry weight production per $\mathrm{m}^{2}$ and day, as well as in $\mathrm{g}$ dry weight produced per mol of photosynthetic active radiation.

For significance levels see Table 2 footnote. 
Table 4 The effect of different $\mathrm{CO}_{2}$ concentrations supplied by flue gas ( $\mathrm{FI}$ ) and one concentration supplied by pure liquid $\mathrm{CO}_{2}$ gas (C) on $\mathrm{pH}$ and dry weight concentration ( $=3, \pm \mathrm{SE}$ ) after four days of $C$. reinhardtii grown in daylight or $70 \%$ daylight (shaded)

\begin{tabular}{|c|c|c|c|c|c|}
\hline \multirow[b]{2}{*}{$\mathrm{CO}_{2}$ treatment } & \multirow[b]{2}{*}{ Light } & \multirow[b]{2}{*}{$\mathrm{pH}$} & \multirow[b]{2}{*}{ Dry w. $\left(\mathrm{mg} \mathrm{l}^{-1}\right)$} & \multicolumn{2}{|c|}{ Dry weight increase } \\
\hline & & & & $\mathrm{g} \mathrm{m}^{-2}$ day $^{-1}$ & $\mathrm{~g} \mathrm{~mol}^{-1}$ \\
\hline $2.6 \% \subset$ & Shaded & $7.19 \pm 0.1$ & $815 \pm 45$ & $11.6 \pm 0.6$ & $1.00 \pm 0.06$ \\
\hline $2.6 \% \subset$ & Daylight & $7.1 \pm 0.0$ & $762 \pm 43$ & $12.4 \pm 0.7$ & $0.72 \pm 0.04$ \\
\hline $2.5 \% \mathrm{FI}$ & Shaded & $7.1 \pm 0.1$ & $960 \pm 18$ & $14.3 \pm 0.7$ & $1.23 \pm 0.06$ \\
\hline $2.5 \% \mathrm{FI}$ & Daylight & $7.1 \pm 0.1$ & $935 \pm 45$ & $14.6 \pm 0.3$ & $0.85 \pm 0.02$ \\
\hline $6.7 \% \mathrm{FI}$ & Shaded & $6.8 \pm 0.1$ & $867 \pm 83$ & $11.9 \pm 0.7$ & $1.03 \pm 0.06$ \\
\hline $6.7 \% \mathrm{FI}$ & Daylight & $6.7 \pm 0.1$ & $780 \pm 46$ & $13.2 \pm 1.3$ & $0.76 \pm 0.07$ \\
\hline $11.4 \% \mathrm{FI}$ & Shaded & $6.5 \pm 0.1$ & $792 \pm 32$ & $12.1 \pm 0.6$ & $1.05 \pm 0.05$ \\
\hline $11.4 \% \mathrm{Fl}$ & Daylight & $6.4 \pm 0.2$ & $797 \pm 41$ & $12.1 \pm 0.5$ & $0.70 \pm 0.03$ \\
\hline \multicolumn{6}{|c|}{ F-value and significance level: } \\
\hline $\mathrm{CO}_{2}$ & & $110^{* * *}$ & $5.14^{*}$ & $5.14^{*}$ & $5.31^{* *}$ \\
\hline Light & & 3.00 & 1.49 & 1.49 & $79.9^{* * *}$ \\
\hline $\mathrm{CO}_{2} \times$ Light & & 1.00 & 0.36 & 0.36 & 0.63 \\
\hline
\end{tabular}

The mean productivity during the four days of the experimental period was calculated as $\mathrm{g}$ dry weight production per $\mathrm{m}^{2}$ and day and as $\mathrm{g}$ dry weight produced per mol of photosynthetic active radiation.

For significance levels see Table 2 footnote.

in the present flue gas were so low that they would have no effect on the growth. However, microalgae possess very high metal uptake capacities and accumulation in the cells will therefore take place (de-Bashan and Bashan 2010). High $\mathrm{CO}_{2}$ concentrations (18-19\%) from pure liquid $\mathrm{CO}_{2}$ gas, however, have recently been found to decrease the dry weight production in the same $C$. reinhardtii strain (Mortensen and Gislerød 2014). Fischer et al. (2006) showed that cells of the same species were more susceptible to high-light stress under high $\mathrm{CO}_{2}$ concentrations than under low concentrations. In the present study, however, the negative effect of the high concentrations seemed to be more related to a high growth rate than to high-light conditions. It can also be noted that the maximum dry weight concentration reached in the algae culture in the flue gas decreased to the same extent (in percentage) as the dry weight production, indicating higher respiration or lower photosynthetic activity in the algae. The negative effect of the 11.4\% flue gas in the present experiment was in contrast to the stimulating effect of flue gas, probably due to lower $\mathrm{O}_{2}$ content, found in some studies on microalgae (Vance and Spalding 2005; Douskova et al. 2009; Kliphuis et al. 2011). Growing Chlorella $s p$. at $2-20 \% \mathrm{CO}_{2}(\mathrm{v} / \mathrm{v})$ simulating flue gas from biogas gave the same effect as growing the algae in food grade $\mathrm{CO}_{2}$ at the same concentrations (Douskova et al. 2010). The environmental conditions could play a role here, and they might also be the reason for the positive effect of the moderate flue gas concentration with $2.5 \% \mathrm{CO}_{2}$ in the present experiment in daylight.

The production at low-level light $24 \mathrm{~h} \mathrm{day}^{-1}\left(6.5 \mathrm{~mol} \mathrm{~m}^{-2}\right.$ day ${ }^{-1}$ PAR) was at the same level (around $14 \mathrm{~g} \mathrm{~m}^{-2} \mathrm{da}^{-1}$ ) as at about a three times higher PAR in daylight, which demonstrates the limitation of the algae as regards utilising the high irradiance level. The productivity in daylight was typical of outdoor production systems and the high productivity was typical of controlled environmental conditions in laboratories (Grobbelaar 2012). The light use efficiency in the present study was found to be the same in the range $75-300 \mu \mathrm{mol} \mathrm{m}^{-2} \mathrm{~s}^{-1}$ PFD. If we assume that all daylight above $300 \mu \mathrm{mol} \mathrm{m}{ }^{-2} \mathrm{~s}^{-1}$ PFD has a value of $300 \mu \mathrm{mol} \mathrm{m} \mathrm{s}^{-1}$, the mean PFD of the daylight will decrease from 199 to about $90 \mu \mathrm{mol} \mathrm{m}^{-2} \mathrm{~s}^{-1}$ or $7.8 \mathrm{~mol} \mathrm{~m}^{-2}$ day $^{-1}$ PAR. This level is comparable to the low-light level with artificial light applied $24 \mathrm{~h}_{\text {day }}{ }^{-1}$. In addition to the constraint caused by light saturation, the presence of a dark period is known to decrease algae growth much more than would be expected from the reduction in PAR (Jacob-Lopez et al. 2009). This means that long day lengths and lower maximum irradiance levels at high latitudes would be beneficial for algae production during the summer months. However, short days and low PAR during large parts of the year make the production of algae impractical in such locations. Growing C. reinhardtii with the aim of using it to produce hydrogen should be based on using daylight in combination with flue gas in order to ensure a positive energy balance (Lam et al. 2012). However, large-scale systems that can utilise the high irradiance levels of daylight much better than today (Slegers et al. 2013) are a prerequisite for future energy-efficient hydrogen production using microalgae. Flue gas is an important $\mathrm{CO}_{2}$ source. However, while care should be taken to ensure a $\mathrm{CO}_{2}$ concentration that is optimal, the presence of pollutants in the flue gas in today's industrial emissions seems to be less of a problem in relation to the growth of the algae. 


\section{Competing interests}

The authors declare that they have no competing interests.

\section{Acknowledgements}

The authors thank 'Borregaard Waste to Energy' with Jørgen Karlsen and staff in Sarpsborg for their hospitality, excellent assistance and for providing the records of the flue gas measurements. This work was done as a part of the project 'Use of solar energy for $\mathrm{CO}_{2}$ capture, algae cultivation and hydrogen production' headed by Dr Stig Borgvang (Bioforsk). It was financed by the Research Council of Norway.

Received: 16 December 2013 Accepted: 23 May 2014

Published online: 18 June 2014

\section{References}

Borkenstein CG, Knoblechner J, Frühwirth H, Schagert M (2011) Cultivation of Chlorella emersonii with flue gas derived from cement plant. J Appl Phycol 23:131-135

de-Bashan LE, Bashan Y (2010) Immobilized microalgae for removing pollutants. Revew of practical aspects. Bioresour Technol 101:1611-1627

Douskova I, Doucha J, Livansky K, Machat J, Novak P, Umysova D, Zachleder V, Vitova M (2009) Simultaneous flue gas bioremediation and reduction of microalgal biomass production costs. Appl Microbiol Biotechnol 82:179-185

Douskova I, Kastanek F, Maleterova Y, Kastanek P, Doucha ZV (2010) Utilization of distillery stilage for energy generation and concurrent production of valuable microalgal biomass in the sequence: Biogas-cogeneration-microalge-products. Energy Conversion Management 51:606-611

Farrelly DJ, Everard CD, Fagan CC, McDonnell KP (2013) Carbon sequestration and the role of biological carbon mitigation: a review. Renew Sust Energ Rev 21:712-727

Fischer BB, Wiesendanger M, Eggen RIL (2006) Growth condition-dependent sensitivity, photodamage and stress response of Chlamydomonas reinhardtii exposed to high light conditions. Plant Cell Physiol 47:1135-1145

Geier SC, Huyer S, Praebst K, Husmann M, Walter C, Buchholz R (2012) Outdoor cultivation of Chlamydomonas reinhardtii for photobiological hydrogen production. J Appl Phycol 24:319-327

Gorman DS, Levine RP (1965) Cytochrome f and plastocyanin: their sequence in the photosynthetic electron transport chain of Chlamydomonas reinhardtii. Proc Natl Acad Sci U S A 54(6):1665-1669

Grobbelaar JU (2012) Microalgae mass culture: the constraints of scaling-up. J Appl Phycol 24:315-318

IPCC (2013) Climate Change 2013: The Physical Science Basis. Contribution of Working Group I to the Fifth Assessment Report of the Intergovernmental Panel on Climate Change. In: Stocker TF, Qin D, Plattner G-K, Tignor M, Allen SK, Boschung J, Nauels A, Xia Y, Bex V, Midgley PM (eds). Cambridge University Press, Cambridge, United Kingdom and New York, NY, USA, www.climate change2013.org

Jacob-Lopez AJ, Scoparo CHG, Lacerda LMCF, Franco TT (2009) Effect of light cycles (night/day) on $\mathrm{CO}_{2}$ fixation and biomass production by microalgae in photobioreactors. Chem Eng Process 48:306-310

Jiang Y, Zhang W, Wang J, Chen Y, Shen S, Liu T (2013) Utilization of simulated flue gas for cultivation of Scenedesmus dimorphus. Bioresour Technol 128:359-364

Jo HJ, Lee DS, Park JM (2006) Modeling and optimization of photosynthetic hydrogen gas Production by green alga Chlamydomonas reinhardtii in sulphur-deprived circumstance. Biotechnol Prog 22:431-437

Kastanek F, Sabata S, Solcova O, Maleterova Y, Kastanek P, Branyikova I, Kuthan K, Zachleder V (2010) In-field experimental verification of cultivation of microalgae Chlorella sp. using flue gas from cogeneration unit as a source of carbon dioxide. Waste Management and Research 28(Kastanek F, Sabata S, Solcova O, Maleterova Y, Kastanek P, Branyikova I, Kuthan K, Zachleder V):961-966

Kliphuis AMJ, Martens DE, Janssen M, Wijfels RH (2011) Effect of $\mathrm{O}_{2}: \mathrm{CO}_{2}$ ratio on the primary metabolism of Chlamydomonas reinhardtii. Biotechnol And Bioengineering 108:2390-2402

Lam MK, Lee KT, Mohamed AR (2012) Current status and challenges on microalgae-based capture. Int J Greenhouse Gas Contr 10:456-469

Matsumoto $\mathrm{H}$, Hamasaki A, Sioji Nlkuta $\mathrm{Y}$ (1997) Influence of $\mathrm{CO}_{2}, \mathrm{SO}_{2}$ and $\mathrm{NO}$ in flue gas on microalgae productivity. J Chem Eng Japan 30:620-624

Mortensen LM (1986) Nitrogen oxides produced during CO2 enrichment III. Effects on tomato at different photon flux densities. New Phytol 104:653-660
Mortensen LM, Gislerød HR (2014) The growth of Chlamydomonas reinhardtii as influenced by high $\mathrm{CO}_{2}$ and low $\mathrm{O}_{2}$ in flue gas from a silicomanganese smelter. J Appl Phycol (in press)

Nguyen AV, Toepel J, Burgess S, Uhmeyer A, Bilfernez O, Doebbe A, Hankamer B, Nixon P, Wobbe L, Kruse O (2011) Time-course global expression profiles of Chlamydomonas reinhardtii during photo-biological $\mathrm{H}_{2}$ production. PLOS ONE 6(12):e29364, doi:10.1371

Skjånes K, Lindblad P, Muller J (2007) $\mathrm{BioCO}_{2}$ - a multidisciplinary, biological approach using solar energy to capture $\mathrm{CO}_{2}$ while producing $\mathrm{H}_{2}$ and high value products. Biomol Eng 24:405-413

Slegers PM, van Beveren PJM, Wijffels RH, van Straten G, Boxtel AJB (2013) Scenario analysis of large scale algae production in tubular photobioreactors. Appl Energy 105:395-406

Sueoka N (1960) Mitotic replication of deoxyribonucleic acid in Chlamydomonas reinhardii. Proc Natl Acad Sci U S A 46:83-91

van den Hende S, Vervaeren H, Boon N (2012) Flue gas compounds and microalgae: (Bio-) chemical interactions leading to biotechnological opportunities. Biotechn Advances 30:1405-1424

Vance P, Spalding MH (2005) Growth, photosynthesis, and gene expression in Chlamydomonas over a range of $\mathrm{CO}_{2}$ concentrations and $\mathrm{CO}_{2} / \mathrm{O}_{2}$ ratios: $\mathrm{CO}_{2}$ regulates multiple acclimation states. Can J Botany 83:796-809

\section{doi:10.1186/s13568-014-0049-4}

Cite this article as: Mortensen and Gislerød: The effect on growth of Chlamydomonas reinhardtii of flue gas from a power plant based on waste combustion. AMB Express 2014 4:49.

\section{Submit your manuscript to a SpringerOpen ${ }^{\circ}$ journal and benefit from:}

- Convenient online submission

- Rigorous peer review

- Immediate publication on acceptance

- Open access: articles freely available online

- High visibility within the field

- Retaining the copyright to your article

Submit your next manuscript at $>$ springeropen.com 